\title{
ORTHODOX RELIGIOUS ORGANIZATIONS IN THE CONTEXT OF TRANSFORMATION OF STATE-CONFESSIONAL RELATIONS (1985-1997): PROBLEMS AND FEATURES (THE CASE OF THE DAGESTAN REPUBLIC) ${ }^{1}$
}

\author{
Olga B. Khalidova \\ Institute for History, Archaeology and Ethnography of the Dagestan Scientific Centre, \\ Russian Academy of Sciences, Makhachkala, Russian Federation \\ Gebek F. Gebekov \\ Institute for History, Archaeology and Ethnography of the Dagestan Scientific Centre, \\ Russian Academy of Sciences, Makhachkala, Russian Federation
}

\begin{abstract}
The increased importance of the religious factor, which influences various aspects of social life, has made it relevant for current academic research. The interrelation of this factor with the political history of Russia makes it one of the most complex and priority areas in the confessional policy of the State, and provokes the rethinking of Russia's policy in the national regions. The issues related to the relationship between official authorities and Orthodox organizations in polyconfessional regions with a predominance of Muslim populations, particularly in Dagestan are of particular interest for us. The absence of historical interpretations on the history of Orthodox organizations in the transitional and post-Soviet periods makes the stated subject topical for identifying and introducing into scientific circulation a specific material that regional studies can provide. Proceeding from the above, in the proposed paper for the first time in regional historiography we've made an attempt to consider the transformation processes in the socio-political situation in the country during the transitional and first decade of the post-Soviet period (1985-1997) and their influence on the development of the Orthodox religion, Christian believers and clergy in Dagestan.

We've made conclusion about the latent process of religious orthodox revival in the republic against the background of the general spiritual crisis in the country during the transitional period of history, conditioned by the continuing policy of "state atheism". Atheistic worldview of governing bodies often influenced the process of building relationships with religious organizations and was characterized as "ambiguous". Religious renaissance in the first half of the 1990s in Dagestan had its own local features, due to the deterioration of the socio-political background of the republic and was accompanied by factors that adversely affect the position of Orthodoxy here.

Authots' contribution: O.B. Khalidova is responsible for the idea, literature review, data interpretation, paper compilation and edition; G.F. Gebekov has carried out the analysis and intepretation of sociological poll data.

Key words: Orthodoxy, religion, power, Dagestan, Russia.

Citation. Khalidova O.B., Gebekov G.F. Orthodox Religious Organizations in the Context of Transformation of State-Confessional Relations (1985-1997): Problems and Features (the Case of the Dagestan Republic). Vestnik Volgogradskogo gosudarstvennogo universiteta. Seriya 4, Istoriya. Regionovedenie. Mezhdunarodnye $\dot{\theta}$ otnosheniya [Science Journal of Volgograd State University. History. Area Studies. International Relations], i. 2018, vol. 23, no. 4, pp. 148-158. (in Russian). DOI: https://doi.org/10.15688/jvolsu4.2018.4.13
\end{abstract}




\title{
ПРАВОСЛАВНЫЕ РЕЛИГИОЗНЫЕ ОРГАНИЗАЦИИ В КОНТЕКСТЕ ТРАНСФОРМАЦИИ \\ ГОСУДАРСТВЕННО-КОНФЕССИОНАЛЬНЫХ ОТНОШЕНИЙ (1985-1997 ГГ.): ПРОБЛЕМЫ И ОСОБЕННОСТИ ВЗАИМООТНОШЕНИЙ В НАЦИОНАЛЬНОМ РЕГИОНЕ (НА ПРИМЕРЕ ДАГЕСТАНА) ${ }^{1}$
}

\author{
Ольга Борисовна Халидова \\ Институт истории, археологии и этнографии ДНЦ РАН, \\ г. Махачкала, Российская Федерация \\ Гебек Фейзулиевич Гебеков \\ Институт истории, археологии и этнографии ДНЦ РАН, \\ г. Махачкала, Российская Федерация
}

\begin{abstract}
Аннотация. Возросшая значимость религиозного фактора, влияющего на различные стороны общественной жизни, на сегодняшний день сделала его актуальным для научных исследований. А взаимосвязь с политической историей России поставила его в один ряд с наиболее сложными и приоритетными направлениями в конфессиональной политике государства, в том числе подвела и к переосмыслению политики России в национальных регионах. Особый интерес в данной плоскости для нас представляют вопросы, связанные с взаимоотношением официальной власти и православных организаций в поликонфессиональных регионах с преобладанием мусульманского населения, в частности в Дагестане. Отсутствие исследовательских исторических интерпретаций об истории православных организаций в переходный и постсоветский периоды делает заявленную тему актуальной для выявления и введения в научный оборот конкретного материала, который может дать регионоведение. Исходя из вышесказанного, в предлагаемой статье впервые в региональной историографии делается попытка рассмотреть трансформационные процессы в общественно-политической обстановке страны в переходный период и первое постсоветское десятилетие (1985-1997 г.) и их влияние на развитие православной религии, христианских верующих и духовенство в Дагестане.

В результате проведенного исследования авторы приходят к выводу о подспудном процессе возрождения православия в республике на фоне общего духовного кризиса в стране в переходный период истории, обусловленный продолжающейся политикой «государственного атеизма». Атеистическое мировоззрение руководящих органов зачастую влияло на процесс выстраивания взаимоотношений с религиозными организациями и характеризовалось как «двусмысленное». Религиозный ренессанс в первой половине 1990-х гг. в Дагестане имел свои локальные особенности, обусловленные ухудшением общественно-политического фона республики, и сопровождался факторами, негативно влияющими на положение православия в республике.

Вклад авторов: О.Б. Халидова - идея, обзор литературы и источников, интерпретация данных, написание статьи и внесение принципиальных изменений в текст, одобрение окончательной версии; Г.Ф. Гебеков - анализ и интерпретация данных социологического опроса, внесение принципиальных изменений в результаты опроса.
\end{abstract}

Ключевые слова: православие, религия, власть, Дагестан, Россия.

Цитирование. Халидова О. Б., Гебеков Г. Ф. Православные религиозные организации в контексте трансформации государственно-конфессиональных отношений (1985-1997 гг.): проблемы и особенности взаимоотношений в национальном регионе (на примере Дагестана) // Вестник Волгоградского государственного университета. Серия 4, История. Регионоведение. Международные отношения. -2018. - Т. 23, № 4. - С. 148158. - DOI: https://doi.org/10.15688/jvolsu4.2018.4.13

\section{Введение}

История православного христианства в Дагестане насчитывает много веков. Проник- нув в Дагестан еще в первые века нашей эры, оно прошло все ступени развития здесь: от расцвета до полного падения, возрождения в дореволюционный период как опоры царской 


\section{ПОЛИТИЧЕСКИЕ НАУКИ И РЕГИОНОВЕДЕНИЕ}

власти до гонений в советские годы. На сегодняшний день, являясь неразрывно связанной с политической историей России, история Русской Православной Церкви и ее роль в политической истории постсоветской России на Кавказе и в частности в Дагестане нуждается в специальном исследовании.

Целью работы является исследование процесса трансформации отношений государства и религиозных организаций в 19851997 гг. и ее влияние на положение православных организаций в Дагестане. Цель исследования предопределила решение следующих задач: проанализировать религиозную обстановку в Дагестане в перестроечный период, рассмотреть эволюцию государственной религиозной политики и отразить новации в отношениях государства и православных организаций, показать локальные особенности и проблемы в развитии православной составляющей в первые годы 1990-х гг. в республике.

\section{Методы}

Методологическая база исследования включает в себя принципы междисциплинарного историко-социологического исследовательского подхода, систематизации и сравнительного анализа данных, исторического беспристрастия. Использование совокупности общеисторических методов научного исследования как проблемно-хронологического и сравнительно-исторического позволит нам показать изменения положения православных организаций в республике, происходившие в переходный период и постсоветский на фоне ухудшения социально-экономического и общественнополитического развития страны. Для подтверждения последнего и выявления оценок в массовом сознании дагестанцев к переменам, происходившим в 80-90-х гг. XX в., мы прибегли к методу социологического опроса.

Материалами для представленного исследования послужили неопубликованные и впервые вводимые в научный оборот документы фонда р-1234 Уполномоченный Совета по делам религий при СМ СССР по ДАССР, г. Махачкала, хранящиеся в Центральном архиве Республики Дагестан (далее - ЦГА РД).

Среди комплексных исследовательских работ, посвященных взаимоотношениям вла- сти и религиозным организациям, на протяжении всего советского периода и постсоветского хочется отметить труды ученых-историков В.А. Алексеева [1], Д.В. Поспеловского [16], протоирея В. Цыпина [26], С.Ю. Симорот [22], И.И. Масловой [12], М.В. Шкаровского [27], М.И. Одинцова [14].

За последние годы в нашей республике издано немало публикаций по религиозной тематике, защищены диссертации. Однако повышенный интерес у исследователей вызывают разработки, связанные с исламом [3; 19; 24]. В этой связи представленная статья в определенной степени не только поможет восполнить образовавшуюся лакуну в современной региональной историографии по православию, но и способствовать предоставлению объективной научной информации новому поколению граждан.

\section{Анализ}

Процесс перестройки в нашей стране повлек за собой коренные изменения не только в политической и экономической структуpax, но и затронул государственно-религиозные отношения. Сохранение стабильности и сдерживание деятельности религиозных объединений приходит на смену форсированному вытеснению религии из общественной жизни в рамках вероисповедного законодательства $[12$, с. 6]. Именно в этот период были заложены серьезные изменения в религиозной политике, взаимоотношениях верующих и государства, их организационных структурах и функциях.

К середине 1980-х гг. по количеству последователей православная религия в республике занимала второе место. Ее исповедовали, в основном, верующие русской национальности, проживающие в городах и в Тарумовском и Кизлярском районах Дагестана. Православные приходы, расположенные на территории Дагестана входили в состав Ставропольской и Бакинской епархии. В 1986 г. в ДАССР функционировало пять церквей: в Махачкале, Кизляре, Дербенте, Хасавюрте и поселке Крайновка [8, л. 19]. Общее количество служителей православного культа составлял 10 человек от 40 до 60 лет. Из них: священников - 7, дьяконов - 
1, псалмовщиков - 2. Только один священнослужитель и один псалмовщик имели среднее духовное образование, остальные - среднее светское образование [8, л. 21]. Посещаемость церквей в дни православных праздников составляла 5-5,5 тыс. человек. Гендерный показатель свидетельствовал, что 80-90 \% из них были женщины. В 1986 г. общее количество освятивших продукты питания составило более 2 тыс. человек, среди которых 100 человек принадлежали цыганской национальности [8, л. 20]. География посещаемости православных церквей по ДАССР была достаточно широкой. Так, в Махачкалинскую церковь на праздники приезжали верующие из г. Каспийска, Избербаша, пос. Сулак, в Дербентскую - из пос. Огни, Белиджи, в Кизлярскую - из с. Тарумовка, в Хасавюртовскую - из Кизилюрта, Гудермеса.

Точную численность верующих в православных приходах ДАССР того времени установить не представляется возможным, так как государственная статистика отсутствует, а в приходах списочный учет не велся. Однако сведения о посещаемости церквей и молитвенных домов во время церковных праздников, о количестве продаж свечей и освященных куличей, об уровне религиозной обрядности все же имеются в архивных документах, хранящихся в фонде Уполномоченного совета по делам религий по ДАССР. Учитывая тот факт, что большинство доходов церкви формировалось за счет пожертвований и платы за совершения религиозных обрядов, советская власть рассматривала религиозную обрядность как один из элементов идеологии Православной церкви в увеличении своей паствы. В этой связи уполномоченные были обязаны систематически предоставлять сведения о религиозной обрядности в Совет по делам религий. В 1986 г. было продано 270 тыс. свечей, 80 тыс. просфоров, 11 тыс. крестиков и 1200 икон на общую сумму 260,5 тыс. рублей [8, л. 19-20].

Увеличение количества продаваемых свечей и доходов церквей говорит, видимо, об улучшении не только финансового положения населения, но и о потребности совершать религиозные обряды. Несмотря на доминантное положение советской вероиспо- ведной политики, ощущалась тенденция изменения отношения государства к религиозным организациям в сторону либерализации. В условиях гласности и демократии население начало обращаться к своим духовным религиозным истокам, вследствие чего возрастает количество людей, принимающих участие в богослужениях и совершающих религиозные обряды.

Отношение к религии и религиозным объединениям в стране одновременно диктовала и сложившаяся международная ситуация. Пристальное внимание к СССР со стороны США и потоки клеветы о преследовании верующих в Советском Союзе, вынуждали советское руководство пойти на уступки в религиозных вопросах. Поводом к трансформационным процессам во взаимоотношениях религиозных организаций и государства стало празднование 1000-летия Крещения Руси в 1988 году. Однако еще в сентябре 1985 г. состоялось заседание Секретариата ЦК КПСС по вопросу «О противодействии зарубежной клерикальной пропаганде в связи с 1000-летием введения христианства на Руси». Прошедшее заседание показало, что первоначальные планы реформирования советского общества предусматривали не достижение диалога государства с церковью и верующими, а лишь некоторое сдерживание атеистической пропаганды в канун церковного юбилея с целью нейтрализации критики положения религии в СССР со стороны общественного мнения Запада [5, л. 1-2].

В противовес государству для служителей культа юбилей являлся знаковым событием. В его подготовке принимали участие священнослужители всей страны, в том числе и Дагестана. В ведомостях по денежным отчислениям православных церквей ДАССР в различные фонды, в Епархиальное управление и реставрацию монастыря, был введен пункт «На празднование 1000-летия Крещения Руси» [20, л. 98, 237, 241, 251]. Согласно отчету Уполномоченного по делам религий по ДАССР С. Девришбекова за 1988 г., основная деятельность православных церквей была связана с подготовкой и празднованием 1000-летия Крещения Руси. К этому юбилею все религиозные общины отремонтировали свои храмы. 27-28 августа 1988 г. 


\section{ПОЛИТИЧЕСКИЕ НАУКИ И РЕГИОНОВЕДЕНИЕ}

состоялся юбилейный праздник в Махачкалинской церкви, на котором присутствовало 5,4 тыс. верующих. Было отмечено посещение указанной церкви 1300 приезжими верующими, из которых $90 \%$ составили женщины, 15-20 \% - молодежи и 30-40 \% - детей [9, л. 230].

Подобный шаг в период «перестройки» означал не только сближение религии и власти в стране, но восстановление роли церкви в обществе. Довольно частым явлением в жизни республики стали встречи с целью налаживания диалогов со служителями религиозных культов разных конфессий, в том числе и православных организаций. Так, на одну из таких встреч был приглашен благочинный церквей Дагестана И.И. Коноплев, выступивший с докладом «Миротворческое служение православных церквей в Дагестане во благо мира» [23, л. 20]. Инициаторами подобных мероприятий выступали Уполномоченный Совета по делам религий по ДАССР и Духовное Управление мусульман Северного Кавказа во главе с муфтием М.Ч. Геккиевым.

Однако на фоне либерального отношения власти к религиозным организациям, постепенно положение православных организаций в национальной республике начало осложняться в виду создавшейся здесь особой общественно-политической ситуации. Все чаще здесь можно было слышать заявления о консолидации поликультурного этнического дагестанского общества под знаменем исламской религии. Широкий резонанс приобретают миграционные процессы среди русскоязычного, как правило, православного населения республики. К 1989 г. в сравнении с 1979 г. русское население республики сократилось на 23534 человека - с 189474 до 165940 [15, с. 24, 25]. Только в Кизлярском районе республики с 1970 по 1989 г. русское население сократилось в 2 раза [11, с. 152]. В связи с этим, уже в 1988 г. отмечалось снижение показателей совершения религиозных обрядов по православным канонам в Дагестане. В подтверждение вышесказанного, нам представляется необходимым привести данные, которые демонстрируют количественные показатели религиозных треб по ДАССР за указанные годы (см. таблицу) [21, л. 9, 96, 238, 252].
Динамика религиозной обрядности

в православных церквях г. Махачкалы, Дербента, Хасавюрта, Кизляра и пос. Крайновка за 1986-1988 г.

\begin{tabular}{|l|c|c|c|c|}
\hline \multirow{2}{*}{ Годы } & \multicolumn{4}{|c|}{ Религиозные требы } \\
\cline { 2 - 5 } & Крещение & Венчание & \multicolumn{2}{|c|}{ Отпевание } \\
\cline { 4 - 5 } & & & Очное & Заочное \\
\hline 1986 & 1192 & 8 & 30 & 1158 \\
\hline 1987 & 896 & 7 & 36 & 1012 \\
\hline 1988 & 660 & 4 & - & 850 \\
\hline
\end{tabular}

Данные таблицы позволяют увидеть, что самыми популярными видами церковной обрядности в указанный период являлись обряд отпевания заочной формы и обряд крещения. Очень низкую степень демонстрировал обряд венчания по церковным канонам. В отчетах Уполномоченного по ДАССР С. Девришбекова отмечалось уменьшение доходности православных церквей и посещаемости за 1988 г. Особенно это было заметно в Крайновской и Дербентской церквях [9, л. 93]. Участие молодежи и мужчин в религиозной жизни стало менее заметным. Многие молодые люди покидали церкви после покупки и зажигания свечей. По этому поводу православные священники утверждали, что «молодым необязательно находиться до конца службы, им достаточно приобрести свечи, просфоры и отметиться заходом в храм» $[9$, л. 93]. Все чаще практиковалась пропаганда заочной обрядности. Верующие старушки ставили свечи за близких, исполняли требы, похоронные поминальные обряды, освещали продукты.

В этой связи можно сделать заключение, что, несмотря на общий подъем религиозной обрядности по стране, в Дагестанской АССР данные были очень низкими и обусловлены общественно-политическими проблемами национального региона. С другой стороны, мы можем предположить, что показатели религиозной статистики намеренно занижались властями республики для центра, поскольку одним из важнейших направлений в своей работе с религиозными объединениями признавали атеизм. Так, при оценке политики руководства республики в конце 1980-х гг., бывший заместитель Уполномоченного по делам религий ДАССР М.Р. Курбанов отмечал в ней двусмысленность. Несмотря на полученные инструкции, где главная задача уполномоченных состояла в том, чтобы верующие имели 
возможность свободно исповедовать свою веру, на деле все обстояло совсем иначе. Объективные аналитические справки с протекцией верующих не всегда получали одобрительную поддержку со стороны начальства и трактовались как покушение на партийные принципы [10].

Повороты в государственно-религиозных отношениях повлекли за собой необходимость разработки новой нормативно-правовой базы. 1 октября 1990 г. Верховным Советом СССР был принят Закон «О свободе совести и религиозных организациях» [17, л. 92-107]. По замечанию Председателя Совета Л.Ф. Колесникова правовой документ «свободен от идеологизированности позиций прежних официальных установок в отношении церкви и юридического несовершенства некоторых других законопроектов» [4, л. 91].

В ДАССР подобный закон был принят 5 мая 1991 г. [6, с. 1], обсуждение которого проходило в сложной общественно-политической обстановке и было связано с организацией выезда паломников для совершения хаджа. В своем выступлении председатель Верховного совета ДАССР М.М. Магомедов обращал внимание на то, что в Дагестане новое законодательство было воспринято как призыв для использования религии в целях возбуждения фанатизма и подогревания националистических чувств [7, с. 2]. Однако, попытка рассмотреть эту проблему немного шире, приводит нас к выявлению и таких факторов, как отсутствие стабильности в обществе, углубляющееся имущественное и материальнофинансовое неравенство, отток сельского населения в города и увеличение количества безработных, инфляция, отсутствие правовой защиты. Социально-экономические и политические преобразования постперестроечного периода закономерно отразились и на духовной сфере общества. С целью глубокого анализа и установления существующих в массовом сознании дагестанцев оценок и отношения к происходившим в 1985-90-х гг. событиям, авторами был проведен социологический опрос $^{2}$.

Так, респондентам был задан вопрос «Как Вы сегодня относитесь к преобразованиям, происходившим в 1985-1999 гг. (внедрение гласности, свободы слова, совести и ве- роисповедания, кооперативов, рыночных отношений)?» с целью выявления существующих в массовом сознании дагестанцев установок. В установках опрошенных превалирует негативная оценка преобразований $(49,8$ \%) и ее наличие в общественном мнении можно объяснить тем, что дагестанцы хорошо помнят последствия изменений основ советского строя, проявившиеся в гиперинфляции, безработице, расслоении дагестанского общества на богатых и бедных, проведение приватизации, которая, на первый взгляд, обеспечивала равный доступ всех граждан к материальным богатствам, страны, а на самом деле, преследовала совершенно иные цели. Доля охарактеризовавших положительно преобразования перестроечного периода более чем в 2 раза меньше по сравнению с подгруппой негативно настроенной части опрошенных и составляет 20,8 \%. Выбор данной позиции респонденты мотивируют позитивными изменениями в обществе, выразившимися в демократизации и гласности, свободе выбора и т. д. Далее, каждый десятый опрошенный по всему массиву демонстрирует полное безразличие к преобразованиям перестроечного периода. Таким образом, полученные результаты исследования являются основанием для вывода о том, что в массовом сознании дагестанских народов в основном превалировала негативная оценка событий 80-90-х гг. $\mathrm{XX}$ столетия.

В жизни православия и православных верующих в Дагестане 1990-е гг. были сложными. На территории республики действовали 11 православных приходов. Из них: 3 церкви - в г. Махачкале, Хасавюрте, Дербенте и 8 молитвенных домов - в г. Буйнакске, Каспийске, Кизляре, Избербаше, а также в с. Тарумовка и Кочубей Тарумовского района и с. Крайновка Кизлярского района.

Еще в период перестройки, когда территория Дагестана и Чечено-Ингушской республики входила в состав Ставропольской епархии, приходы Дагестана и Чечено-Ингушетии не были привлекательными для православного священства. Для митрополита Гедеона, возглавлявшего в то время Ставропольскую епархию, всегда представляло большую трудность отправить туда священников на постоянное служение [2, с. 93]. Это, в свою оче- 
редь, обостряло кадровый дефицит православных священнослужителей, отсутствие духовного образования у которых зачастую не позволяло проводить духовную работу среди молодежи и взрослого населения должным образом. Существовала проблема с регистрацией православных храмов в республике. Одновременно в республике сложилась ситуация, когда православное население должно как можно меньше себя проявлять, а всякая миссионерская деятельность с их стороны могла привести к обострению отношений с мусульманским населением республики, для которых ислам на протяжении многих веков оставался единственно «правильной» религией с четкими укоренившимися в обществе установками и правилами.

В связи с этим, в дагестанском обществе продолжали преобладать тенденции оттока русского православного населения. Особенно усилились темпы роста миграции среди русских после начала военных действий в соседней Чечне в 1994 г., взрывов жилых домов в ноябре 1996 г. в г. Каспийске, а затем и 4 сентября 1999 г. в г. Буйнакске, военных событий в августе 1999 г. на территории нашей республики. Ареалами миграции становились близлежащие территории (Ставропольский и Краснодарский края, Ростовская область). Экспертные опросы среди респондентов русской национальности в прошлом проживавших в Дагестане и мигрировавших сюда выявили ряд причин их переселения, в том числе «изза детей, из-за неуверенности в их будущем», «ощущение скованности при проявлении своей религиозной принадлежности (ношение открыто крестика и пр.)», бытовые причины. Некоторые респонденты отмечали для себя «низкий уровень возможностей в Дагестане, нежели в том же Ставропольском крае», а также «развитость на кавказских территориях клановой системы» [25, с. 147-153].

Начало военных действий в Чечне (1994 г.) и сильный отток из республики русского населения, по словам отца Николая, бывшего настоятеля Свято-Успенского собора г. Махачкалы, сказались на финансовом положении церкви в Дагестане. Поддерживая свое существование за счет наполнения «церковной кружки», резкое сокращение паствы привело к тому, что священники получали по
400 рублей в месяц, а певчие и «трудовики»по 200 рублей [13, с. 163]. Кроме того, денежные доходы подобного рода производились с задержками. Учитывая то, что в 1994 г. в Дагестане среднедушевой прожиточный минимум населения в год составлял 92889 рублей, а в месяц, соответственно, 7740 рублей [18, с. 111], эта сумма была весьма ощутимо маленькой. Малочисленный состав прихожан способствовал прекращению работы воскресных школ при церквах в Махачкале и Кизляpe $[13$, с. 162]. Численность паствы сократилась в $3-5$ раз.

Положение православной церкви в Дагестане осложняла активная деятельность протестантских проповедников, успехи которых были обусловлены опытом и постоянным настроем на проповедь Евангелия. Это, в свою очередь, не могло не беспокоить православное духовенство.

С другой стороны, все обозначенные проблемы имели «оборотную сторону» После 1995 г. положительным событием в жизни православия явилось возрождение православной культуры, одним из проявлений которого стал процесс воссоздания храмов на месте старых церквей, действовавших до революции. Так, на месте уничтоженного в советские годы православного храма в селе Коктюбей была восстановлена церковь святых Петра и Павла. В Кизляре проводилась активная работа по восстановлению женского монастыря.

\section{Результаты}

Процесс религиозного возрождения православия в республике в переходный период истории происходил на фоне общего духовного кризиса в стране и был обусловлен продолжающейся политикой «государственного атеизма». Атеистическое мировоззрение руководящих органов зачастую влияло на процесс выстраивания взаимоотношений с религиозными организациями и характеризовалось как «двусмысленное». Религиозный ренессанс в первой половине 1990-х гг. в Дагестане имел свои локальные особенности, был обусловлен ухудшением общественно-политического фона республики и сопровождался факторами, негативно влияющими на положение здесь православия. 


\section{ПРИМЕЧАНИЯ}

${ }^{1}$ Исследование выполнено при финансовой поддержке РГНФ, проект 16-01-00038 «Развитие Дагестана в процессе интеграции в общероссийское пространство в условиях трансформации и модернизации государственного строя в 1985-2010 годах».

${ }^{2}$ Социологический опрос по изучению был проведен методом случайного отбора и охватил все 3 географические зоны республики (равнинная, предгорная и горная) в г. Махачкале, Каспийске, Дербенте, Кизляре и горных районах республики (количество респондентов - 743).

\section{СПИСОК ЛИТЕРАТУРЫ}

1. Алексеев, В. А. Постперестройка: несвободная совесть? Интервью, беседы с религиозными деятелями, статьи о проблемах свободы совести и церковно-государственных отношениях в России / В. А. Алексеев. - М. : Россия молодая, 1992. $-62 \mathrm{c}$.

2. Бурдо, М. Атлас современной религиозной жизни России / М. Бурдо, С. Филатов. - М. ; СПб. : Летний сад, 2005. - Т. 1. -621 с.

3. Далгатов, А. Г. Борьба против влияния мусульманского духовенства в Дагестане в 19201930-е гг. / А. Г. Далгатов, И. Х. Сулаев // Вопросы истории. - 2010. - № 6. - С. 77-85.

4. Доклад председателя Совета по делам религий при Совете Министров РСФСР Л. Ф. Колесникова по поводу принятия Закона РСФСР «О свободе совести и религиозных организациях» от 1 августа 1990 г. // Государственный архив Российской Федерации (ГАРФ). - Ф. А-661. - Оп. 1. - Д. 20.

5. Заседание секретариата ЦК КПСС по вопросу «О противодействии зарубежной клерикальной пропаганде в связи с 1000-летием введения христианства на Руси» от 10 сентября 1985 г. // Российский Государственный архив новейшей истории (РГАНИ). - Ф. 89. - ОП. 25. - Д. 10.

6. Из Закона ДАССР «О свободе совести и религиозных организациях», принятой постановлением Верховного Совета Дагестанской АССР от 5 мая 1991 г. // Дагестанская правда. - 1991. - 14 мая.

7. Из выступления председателя Верховного Совета ДАССР М. М. Магомедова на XV сессии Верховного Совета Дагестанской АССР от 18 сентября 1991 г. // Дагестанская правда. - 1991. - 19 дек.

8. Информационный отчет о деятельности религиозных организаций и состоянии контроля за соблюдением законодательства о религиозных культах в Дагестанской АССР от 26 января 1987 г. // Центральный Государственный архив Республики Дагестан (ЦГА РД). - Ф. p-1234. - Оп. 5. - Д. 37.
9. Информационный отчет Уполномоченного Совета по ДАССР за 1988 год // ЦГА РД. Ф. p-1234. - Оп. 5. - Д. 37.

10. Курбанов, М. Р. Совет по делам религий в фокусе времени / М. Р. Курбанов // Народы Дагестана: республиканский общественно-политический журнал. - 2010. - 23 июля (№ 4). - Электрон. текстовые дан. - Режим доступа: http://www.narodidagestana. ru/ vipusk (дата обращения: 01.07.2016). - Загл. с экрана.

11. Лысенко, Ю. М. Северный Дагестан 19572000 гг. (аспекты социально-экономического развития г. Кизляра, Кизлярского и Тарумовского районов) / Ю. М. Лысенко. - Махачкала : Народы Дагестана, 2005. - $164 \mathrm{c}$.

12. Маслова, И. И. Вероисповедная политика в СССР: поворот курса (1985-1991 гг.) / И. И. Маслова. - М. : МНЭПУ, 2005. - 239 с.

13. Муртузалиев, С. И. Христианство в современном Дагестане / С. И. Муртузалиев // «Религиозный фактор в жизни современного дагестанского общества» : материалы Республиканской научно-практической конференции (27 октября 2000 г.). - Махачкала : Изд. дом «Новый день», 2002. - С. 159-165.

14. Одинцов, М. И. Русская Православная церковь в XX веке: история, взаимоотношения с государством и обществом / М. И. Одинцов. - М. : Центральный дом духовного наследия общества «Знание», 2002. - 312 c.

15. Основные национальности Республики Дагестан (численность, демографические показатели, расселение) : стат. сб. / под ред. Э. Ф. Кисриева. Махачкала : Статистика, 1995. - 37 с.

16. Поспеловский, Д. В. РПЦ в ХХ веке / Д. В. Поспеловский. - М. : Республика, 1995. $511 \mathrm{c}$.

17. Проект Закона РСФСР «О свободе совести и религиозных организациях» № 2445 от 01.08.1990 г. // ГАРФ. - Ф. А-661. - ОП. 1. - Д. 20.

18. Регионы России : стат. сб. / Госкомстат России.- М. : Госкомстат России, 1998. - Т. 1. - 797 с.

19. Салахбекова, 3. А. Власть и мусульманское духовенство Дагестана: история взаимоотношений (1920 -1940 гг.) : автореф. дис. ... канд. ист. наук : 07.00.02 / Салахбекова Зарипат Абдурахмановна. Махачкала, 2003. - 30 с.

20. Сведения о доходности и отчислениях православных церквей ДАССР за 1986-1987 гг. // ЦГА РД. - Ф. p-1234. - Оп. 5. - Д. 37.

21. Сведение о религиозной обрядности Знаменской церкви г. Хасавюрта, Крайновской церкви, Свято-Успенской церкви г. Махачкалы, Кизлярской и Дербентской церквей за 1987 г. // ЦГА РД. Ф. p-1234. - Оп. 5. - Д. 41.

22. Симорот, С. Ю. Власть и религия. История отношений (1941-1990) / С. Ю. Симорот. - Хабаровск : Изд-во ТОГУ, 2014. - 139 с. 
23. Справка Уполномоченного Совета по делам религий при Совете Министров СССР по ДАССР С. А. Девришбекова о работе с духовенством в республике // ГАРФ. - Ф. p-6991. - Оп. 6. Д. 2996.

24. Сулаев, И. Х. Государство и мусульманское духовенство в 1920-1930-х гг.: из истории взаимоотношений / И. Х. Сулаев // Отечественная история. -2007 . - № 6. - С. 144-155.

25. Халидова, О. Б. «Дагестанские русские» в регионах Юга России в 1980-2010 гг:: Особенности адаптации в материнском этносе / О. Б. Халидова // Этнокультурные ландшафты на постсоветском пространстве: проблемы и особенности формирования дагестанского компонента (к 90-летию ИИАЭ ДНЦ РАН) : коллектив. моногр. / О. Б. Халидова [и др.] Махачкала : ИИАЭ ДНЦРАН, 2014. - С. 147-153.

26. Цыпин, В. История РПЦ. Синодальный и новейший периоды (1700-2005 гг.) / В. Цыпин. - Изд. 2-е, перераб.-М. : Изд-во Сретенского монастыря, 2006. $816 \mathrm{c}$.

27. Шкаровский, М. В. Русская православная церковь. ХХ век / М. В. Шкаровский. - М. : Вече, 2010. $-480 \mathrm{c}$.

\section{REFERENCES}

1. Alekseev V.A. Postperestroyka: nesvobodnaya sovest? Intervyu, besedy s religioznymi deyatelyami, statyi o problemakh svobody sovesti $i$ tserkovno-gosudarstvennykh otnosheniyakh $v$ Rossii [Post-Restructuring: Unfree Conscience? Interviews, Conversations with Religious Figures, Articles on the Problems of Freedom of Conscience and Church-State Relations in Russia]. Moscow, Rossiya molodaya Publ., 1992. 62 p.

2. Burdo M., Filatov S. Atlas sovremennoy religioznoy zhizni Rossii [Atlas of the Modern Religious Life of Russia]. Moscow; Saint Petersburg, Letniy sad Publ., 2005, vol. 1. 621 p.

3. Dalgatov A.G., Sulaev I.Kh. Borba protiv vliyaniya musulmanskogo dukhovenstva $\mathrm{v}$ Dagestane v 1920-1930-e gg. [The Struggle against the Influence of the Muslim Clergy in Dagestan in 1920-1930]. Voprosy istorii [Issues of History], 2010, no. 6 , pp. 77-85.

4. Doklad predsedatelya Soveta po delam religiy pri Sovete Ministrov RSFSR L. F. Kolesnikova po povodu prinyatiya Zakona RSFSR «O svobode sovesti i religioznykh organizatsiyakh» ot 1 avgusta $1990 \mathrm{~g}$. [Report of the Chairman of the Council for Religious Affairs under the Council of Ministers of the RSFSR L.F. Kolesnikov on the Adoption of the RSFSR Law "On Freedom of Conscience and Religious Organizations" of August 1, 1990]. Gosudarstvennyy arkhiv Rossiyskoy Federatsii [State Archives of the Russian Federation], F. A-661, Op. 1, D. 20.

5. Zasedanie sekretariata TsK KPSS po voprosu «O protivodeystvii zarubezhnoy klerikalnoy propagande v svyazi s 1000-letiem vvedeniya khristianstva na Rusi» ot 10 sentyabrya 1985 g. [Meeting of the Secretariat of the Central Committee of the CPSU "On Countering Foreign Clerical Propaganda in Connection with the $1000^{\text {th }}$ Anniversary of Christianity in Russia" of September 10, 1985]. Rossiyskiy Gosudarstvennyy arkhiv noveyshey istorii [Russian State Archive of Contemporary History], F. 89, Op. 25, D. 10.

6. Iz Zakona DASSR «O svobode sovesti i religioznykh organizatsiyakh», prinyatoy postanovleniem Verkhovnogo Soveta Dagestanskoy ASSR ot 5 maya 1991 g. [From the Dagestan ASSR Law "On Freedom of Conscience and Religious Organizations" Adopted by the Decision of the Supreme Council of the Dagestan ASSR of May 5, 1991]. Dagestanskaya Pravda, 1991, May 14.

7. Iz vystupleniya predsedatelya Verkhovnogo Soveta DASSR M. M. Magomedova na XV sessii Verkhovnogo Soveta Dagestanskoy ASSR ot 18 sentyabrya 1991 g. [From the Speech of the Chairman of the Supreme Council of the Dagestan Republic M.M. Magomedov at the $15^{\text {th }}$ Session of the Supreme Council of the Dagestan ASSR of September 18, 1991]. Dagestanskaya Pravda, 1991, December 19.

8. Informatsionnyy otchet o deyatelnosti religioznykh organizatsiy i sostoyanii kontrolya za soblyudeniem zakonodatelstva o religioznykh kultakh v DagestanskoyASSR ot 26 yanvarya $1987 \mathrm{~g}$. [Information Report on the Activities of Religious Organizations and the Status of Monitoring the Compliance with Legislation on Religious Cults in the Dagestan ASSR of January 26, 1987]. Tsentralnyy Gosudarstvennyy arkhiv Respubliki Dagestan [Central State Archive of the Republic of Dagestan], F. r-1234, Op. 5, D. 37.

9. Informatsionnyy otchet Upolnomochennogo Soveta po DASSR za 1988 god [Information Report of the Authorized Council for Dagestan ASSR for 1988]. Tsentralnyy Gosudarstvennyy arkhiv Respubliki Dagestan [Central State Archive of the Republic of Dagestan], F. r-1234, Op. 5, D. 37.

10. Kurbanov M.R. Sovet po delam religiy v fokuse vremeni [Council on the Issues of Religions: Diachronic Aspect]. Narody Dagestana: respublikanskiy obshchestvenno-politicheskiy zhurnal, 2010, no. 4 (July 23). URL: http://www. narodidagestana.ru/vipusk (accessed 1 July 2016).

11. Lysenko Yu.M. Severnyy Dagestan 19572000 gg. (aspekty sotsialno-ekonomicheskogo razvitiya g. Kizlyara, Kizlyarskogo i Tarumovskogo rayonov) [Northern Dagestan, 1957-2000 (Aspects of Socio-Economic Development of Kizlyar, Kizlyar 
District and Tarumovsky District)]. Makhachkala, Narody Dagestana Publ., 2005. 164 p.

12. Maslova I.I. Veroispovednaya politika $v$ SSSR: povorot kursa (1985-1991 gg.) [Religious Politics in the USSR: Turn of the Course (1985-1991)]. Moscow, MNEPU Publ., 2005. 239 p.

13. Murtuzaliev S.I. Khristianstvo v sovremennom Dagestane [Christianity in modern Dagestan]. «Religioznyy faktor $v$ zhizni sovremennogo dagestanskogo obshchestva»: Materialy Respublikanskoy nauchno-prakticheskoy konferentsii (27 oktyabrya 2000 g.) [Religious Factor in the Life of Modern Dagestan Society: Proceedings of the Republican Research and Practice Conference (October 27, 2000)]. Makhachkala, Novyy den Publ., 2002, pp. 159-165.

14. Odintsov M.I. Russkaya Pravoslavnaya tserkov $v$ XX veke: istoriya, vzaimootnosheniya s gosudarstvom $i$ obshchestvom [Russian Orthodox Church in the $20^{\text {th }}$ Century: History, Relationship with the State and Society]. Moscow, Znanie Publ., 2002. 312 p.

15. Osnovnye natsionalnosti Respubliki Dagestan (chislennost, demograficheskie pokazateli, rasselenie): stat. sb. [Main Nationalities of the Dagestan Republic (Number, Demographic Indicators, Resettlement): Statistical Collection]. Makhachkala, Statistika Publ., 1995. 37 p.

16. Pospelovskiy D.V. RPTs $v X X$ veke [Russia Orthodoxy Church in the $20^{\text {th }}$ Century]. Moscow, Respublika Publ., 1995. 511 p.

17. Proekt Zakona RSFSR «O svobode sovesti i religioznykh organizatsiyakh» № 2445 ot 1.08 .1990 g. [Draft Law of the RSFSR “On Freedom of Conscience and Religious Organizations" No. 2445 of August 1, 1990]. Gosudarstvennyy arkhiv Rossiyskoy Federatsii [State Archives of the Russian Federation], F. A-661, Op. 1, D. 20.

18. Regiony Rossii: stat. sb. [Russian Regions: Statistical Collection]. Moscow, Goskomstat Rossii Publ., 1998, vol. 1. 797 p.

19. Salahbekova Z.A. Vlast $i$ musulmanskoe dukhovenstvo Dagestana: istoriya vzaimootnosheniy (1920-1940 gg.): avtoref. dis. ... kand. ist. nauk [Power and the Muslim Clergy of Dagestan: the History of Relationships (1920-1940). Dr. hist. sci. abs. diss]. Makhachkala, 2003.34 p.

20. Svedeniya o dokhodnosti i otchisleniyakh pravoslavnykh tserkvey DASSR za 1986-1987 gg. [Information on the Profitability and Deductions of the Orthodox Churches of the Dagestan ASSR for 19861987]. Tsentralnyy Gosudarstvennyy arkhiv Respubliki Dagestan [Central State Archive of the Republic of Dagestan], F. r-1234, Op. 5, D. 37.
21. Svedenie o religioznoy obryadnosti Znamenskoy tserkvi g. Khasavyurta, Kraynovskoy tserkvi, Svyato-Uspenskoy tserkvi g. Makhachkaly, Kizlyarskoy i Derbentskoy tserkvey za 1987 g. [Information on the Religious Ritual of the Znamensky Church in Khasavyurt, the Kraynivsky Church, the Holy Dormition Church in Makhachkala, the Kizlyar and Derbent Churches for 1987]. Tsentralnyy Gosudarstvennyy arkhiv Respubliki Dagestan [Central State Archive of the Republic of Dagestan], F. r-1234, Op. 5, D. 41.

22. Simorot S.Yu. Vlast $i$ religiya. Istoriya otnosheniy (1941-1990) [Power and Religion. The History of Relations (1941-1990)]. Khabarovsk, Izd-vo TOGU, 2014. 139 p.

23. Spravka Upolnomochennogo Soveta po delam religiy pri Sovete Ministrov SSSR po DASSR S. A. Devrishbekova o rabote s dukhovenstvom $\mathrm{v}$ respublike [Certificate of the Authorized Council for Religious Affairs under the Council of Ministers of the USSR on Dagestan ASSR S. A. Devrishbekov on Work with the Clergy in the Republic]. Gosudarstvennyy arkhiv Rossiyskoy Federatsii [State Archives of the Russian Federation], F. r-6991, Op. 6, D. 2996.

24. Sulaev I.Kh. Gosudarstvo i musulmanskoe dukhovenstvo v 1920-1930-kh gg.: iz istorii vzaimootnosheniy [State and Muslim Clergy in the 1920s-1930s: from the History of Relationship]. Otechestvennaya istoriya, 2007, no. 6, pp. 144-155.

25. Khalidova O.B. «Dagestanskie russkie» v regionakh Yuga Rossii v 1980-2010 gg.: Osobennosti adaptatsii v materinskom etnose ["Dagestan Russians" in the Regions of the South of Russia in 1980-2010: Peculiarities of Adaptation in the Maternal Ethnos]. Khalidova O.B., ed. Etnokulturnye landshafty na postsovetskom prostranstve: problemy $i$ osobennosti formirovaniya dagestanskogo komponenta (k 90-letiyu IIAE DNTS RAN): kollektiv. monogr. [Ethnocultural Landscapes in the post-Soviet Space: Problems and Peculiarities of the Formation of the Dagestan Component (to the $90^{\text {th }}$ Anniversary of the Institute of Nuclear Research of the Russian Academy of Sciences). Collective Monograph]. Makhachkala, IIAE DNTs RAN, 2014, pp. 147-153.

26. Tsypin V. Istoriya RPTs. Sinodalnyy $i$ noveyshiy periody (1700-2005 gg.) [The History of Russian Orthodox Church. Synodal and New Periods (1700-2005)]. Moscow, Izd-vo Sretenskogo monastyrya, 2006. $816 \mathrm{p}$.

27. Shkarovskiy M.V. Russkaya pravoslavnaya tserkov. $X X$ vek [Russian Orthodox Church. The $20^{\text {th }}$ Century]. Moscow, Veche Publ., 2010. 480 p. 


\section{ПОЛИТИЧЕСКИЕ НАУКИ И РЕГИОНОВЕДЕНИЕ}

\section{Information about the Authors}

Olga B. Khalidova, Candidate of Sciences (History), Researcher, Department of Modern and Contemporary History of Dagestan, Institute for History, Archaeology and Ethnography of the Dagestan Scientific Centre, Russian Academy of Sciences, M. Yaragskogo St., 75, 365030 Makhachkala, Russian Federation, o.khalidova2011@mail.ru, http://orcid.org/0000-0002-3454-9427

Gebek F. Gebekov, Candidate of Sciences (History), Researcher, Department of Sociology, Institute for History, Archaeology and Ethnography of the Dagestan Scientific Centre, Russian Academy of Sciences, M. Yaragskogo St., 75, 365030 Makhachkala, Russian Federation, gebecoff@mail.ru, http:// orcid.org/0000-0002-2950-0610

\section{Информация об авторах}

Ольга Борисовна Халидова, кандидат исторических наук, научный сотрудник Отдела новой и новейшей истории Дагестана, Институт истории, археологии и этнографии ДНЦ РАН, ул. М. Ярагского, 75, 365030 г. Махачкала, Российская Федерация, o.khalidova2011@mail.ru, http:/ /orcid.org/0000-0002-3454-9427

Гебек Фейзулиевич Гебеков, кандидат исторических наук, научный сотрудник Отдела социологии, Институт истории, археологии и этнографии ДНЦ РАН, ул. М. Ярагского, 75, 365030 г. Махачкала, Российская Федерация, gebecoff@mail.ru, http://orcid.org/0000-0002-2950-0610 